Article

\title{
Ambidextrous Leadership and Sustainability-Based Project Performance: The Role of Project Culture
}

\author{
Junwei Zheng ${ }^{1} \stackrel{(D)}{ }$, Guangdong $\mathrm{Wu}^{2}$ (D), Hongtao $\mathrm{Xie}^{1, *}$ and $\mathrm{Hui} \mathrm{Xu}^{3}$ \\ 1 Faculty of Civil Engineering and Mechanics, Kunming University of Science and Technology, \\ Kunming 650500, China; zjw1989@kmust.edu.cn \\ 2 Department of Construction Management, Jiangxi University of Finance and Economics, Nanchang 330013, \\ China; gd198410@163.com \\ 3 School of Economics and Management, Chongqing University of Posts and Telecommunications, \\ Chongqing 400065, China; xuhui@cqupt.edu.cn \\ * Correspondence: xhtkmust@kmust.edu.cn; Tel.: +86-137-5914-3607
}

Received: 21 November 2017; Accepted: 10 December 2017; Published: 14 December 2017

\begin{abstract}
Most studies in the project management field emphasized the effects of leaders or managers, but these effects have rarely been examined at the project level. To cover this research gap, this study applies organizational ambidexterity theory to examine the effects among ambidextrous leadership, ambidextrous culture and sustainability-based project performance. Using a valid sample of 217 project leaders and members from Chinese construction projects, the method of multiple linear regression was adopted to assess the direct relationship among ambidextrous leadership, ambidextrous culture and project performance. Moreover, the bootstrapping technique through structural equation modeling, has been used to analyze the mediating effect of ambidextrous culture. Additionally, the sample data was divided into different groups according to the median value of the variables to conduct the ANOVA and to assess the within-group differences. The results indicated a positive and direct relationship that ambidextrous leadership has on project performance and ambidextrous culture. In addition, there was also a mediating impact of ambidextrous leadership on project performance via ambidextrous culture. Thus, ambidextrous leadership combined with transformational leadership as well as transactional leadership likely has a stronger positive impact on project performance through fostering the adaptive culture and consistent culture. Our findings contribute to an in-depth understanding of the role of the leader and culture for project outcomes. The project-based organization in construction projects could train project leaders' ambidextrous leadership behavior to facilitate the formation of an ambidextrous culture and to increase project performance. Moreover, this study enriches the existing literature on leadership and project management by highlighting the important path of ambidextrous leadership and ambidextrous culture on the performance at the project level and going beyond the single leadership behavior or single culture.
\end{abstract}

Keywords: sustainability-based project performance; ambidextrous leadership; project ambidextrous culture; mediation model; bootstrapping

\section{Introduction}

Numerous studies have indicated that the construction industry has a low efficiency level compared to manufacturing or electricity industries [1]. To meet the requirements of technological, organizational and sustainable development, construction companies or project-based organizations should seek new operational and managerial approaches to achieve a more efficient production or construction process [2,3]. The project is considered as a creative environment, where different parties with various skills and knowledge are addressing specific problems within limited time frame and 
resources [4]. The project-based character burdens the project management and its implementation with paradoxes and tensions, then project management processes are complex and nonlinear, which leads to an ever-changing cycle of events or requirements [5]. Similar to the yin and yang organization context [6], there is a balance between hard elements (e.g., discipline) and soft elements (e.g., trust). The organizational ambidexterity is necessary but difficult to be implemented at the project level in order to achieve the pre-defined goals and being innovative under the discipline. Although the firm-level ambidexterity is a topic recently discussed [7], issues such as organizational ambidexterity at the project level have not yet been addressed or developed in the literature.

Organizational ambidexterity refers to the ability of an organization to be aligned and efficient in the organizational management to meet the development demands, while adapting to a changing organizational environment $[8,9]$. Ambidexterity is proposed, which arises from the organizational context [10], and the leadership and culture are investigated to the problem that how the organizational characteristics manage and embrace conflicts or contradictions [11,12]. When the question turns to a complex construction project setting, a single leadership style cannot promote the project or the organization effectively. Instead, a combination of different leadership styles, which are flexibly adopted to the ever-changing environments within the project construction process, has been considered to be more effective. In other words, leadership in construction projects has to match the complexity and the pace of construction [13]. The ever-changing pace confronting temporal construction project-based organization has resulted in calls for more adaptive and flexible leadership [14]. In the existing literature, leadership is focusing on stable leader traits and styles, e.g., transformational leadership [15,16], and transactional leadership [17,18]. However, a simple linear relationship between leadership and organizational performance cannot account for the temporal dynamics in the construction projects. Thus, we assume that the flexible and complementary leadership behaviors could be better to correspond to the changing requirements and to promote an optimal project execution. In summary, the flexibility and supplementary of leadership behaviors are called ambidextrous leadership, and this leads us to the proposition that project performance requires ambidexterity rather than unitary management approach.

Besides, organizational culture has several traits, such as adaptability in response to external conditions, normative integration and consistency [19]. Consistency ensures stability and direction, while adaptability allows for change and flexibility [20]. Gibson and Birkinshaw [10] state that an organization should avoid both too much discipline as well as too much support or trust. However, the question regarding the type of organizational culture that could promote and enable the organizational ambidexterity remains [21]. Furthermore, the organizational culture has rarely been conceptually tested in the organizational ambidexterity literature. The second proposition is to examine the ambidextrous culture in a project (composed of adaptive and consistent culture), playing the role of a mediator between ambidextrous leadership and project performance.

Although the concepts of ambidextrous organization or organizational ambidexterity are not new, being so far applied to leadership or culture, the idea of ambidextrous leadership and ambidextrous culture has not yet been discussed within a complex construction project setting or even a temporary project-based organization. More specifically, the impact of ambidexterity at a lower level, e.g., the project level, has not yet been discussed in the existing literature. As such, we expand the concept of ambidexterity to the leadership and culture observed at the project level as well as to project members. The goal of this paper is to empirically assess the role played by the ambidexterity theory of leadership and culture in project management. This study aims to contribute to the existing strand of literature on leadership in construction projects or project-based organizations by providing evidence that leaders who possess high levels of both transformational and transactional behaviors are more successful and effective in terms of promoting and improving the overall project performance. This paper also provides a series of practical and managerial implications, thus the results might be useful either in the training or development of new leadership behaviors or styles or in the fostering of the existing organizational 
culture in order to increase the efficiency of project management. Moreover, several directions for future research will be outlined in light of the current findings.

The findings of this paper contribute to theory and practice in several ways. First, the ambidextrous lens are used to examine leader behavior and culture in the project-based organization. Although prior literature has considered organizational ambidexterity, the conceptualization of organizational ambidexterity in construction projects is presented in this paper, which generates new directions in project management research. Second, the ambidextrous phenomena in organizations deriving from the West is bridged and extended. Aligned with the Eastern thinking, our research is conducted in China, and our understanding of organizational ambidexterity and effective approaches to them are integrated and broadened to provide insights for researchers and project leaders in the construction project context.

\section{Theory and Hypotheses}

\subsection{Organizational Ambidexterity, Ambidextrous Leadership and Culture}

The term organizational ambidexterity was firstly discussed by Duncan [8], being defined as the ability of an organization to be aligned and efficient in covering business demands while simultaneously adapting to environmental changes [10,22]. Gibson and Birkinshaw [10] stated that ambidexterity resulted from the organizational context. Previous literature has also investigated leadership characteristics that enable members to embrace organizational contradictions [11,12], and the relationship between organizational ambidexterity and organizational performance $[10,23]$. Organizational ambidexterity has been studied in relation to the organizational ability to simultaneously target transformations, stability, flexibility and efficiency [22]. In contrast, few studies focused on how organizations achieve the organizational ambidexterity [24], nor on the organizational ambidexterity in temporary organization or project-based organization.

The ambidexterity theory of leadership discussed the interaction between two complementary leadership behaviors [25], e.g., opening and closing behaviors [26], directive and empowering leadership [27], or transformational and transactional leadership [14]. A combination of different leadership styles or behaviors has been suggested to be more effective for the changing environments and organizational requirements [25]. Recent studies have investigated the stable leader traits and general leadership behaviors, focusing on a stable and inflexible leadership. For example, Rosing et al. [25] proposed that the temporally flexible leadership was necessary for the dynamic organizational change. A single leadership may be not appropriate for continuously-changing organizational situation, and the relationship between single leadership and organizational outcomes cannot account for the organizational temporal dynamics [28]. Baškarada et al. [29] stated that effective leadership required a balance between transformational leadership and transactional leadership. In other words, the integration of different leadership behaviors or the complementary leadership behaviors were corresponded to the organizational dynamic requirements that a single one could not be able to meet. Moreover, different leadership styles would have different impacts on organizational ambidexterity [30]. Hence, the central idea of ambidextrous leadership was that complex organizational activities were matched by en equally complex leadership approach, i.e., the complementary leadership behaviors (e.g., opening and closing behaviors, or transformational and transactional leadership) [26]. For instance, Schulte et al. [31] used the communities of practice as a case study and viewed the ambidextrous leadership in the form of opening and closing leadership behaviors as a matched approach with the ambidextrous nature of community forms. Tuan [32] suggested that an ambidextrous leadership that is comprised of opening leadership and closing leadership behaviors, could contribute to the public organizational reform. Vargas [33] provided evidence that a blend of transformational leadership and transactional leadership would facilitate the achievement of high organizational performance. The ambidexterity theory of leadership therefore stated that the interaction of two different leadership behaviors could predict or promote the outcomes 
at the individual or organizational level, in such a way that organizational outcomes were high when both types of leadership behaviors were high [25]. Organizational ambidexterity may be promoted and fostered by ambidextrous leadership [34], the behaviors of which could switch flexibly and reconcile the conflicts or tensions [35].

Organizational culture has been defined as the underlying values, beliefs and principles, which serve as the basis for the organization management [36], forming the informal part of the organizational context to complement the formal part (e.g., the system) [37]. The organizational culture has several specific features, such as adaptability in response to external situations, and normative integration and consistency [19]. Consistency ensures stability and direction, while adaptability allows for change and flexibility [20]. Both traits of organizational culture were taken as organizational management approaches to cope with the dual problems of stability and flexibility as well as the internal integration and external adaptation [38]. The dual aspects of the organizational culture (i.e., consistency and adaptability) in the process of organization management were further developed as the concept of ambidextrous organizational culture [19]. Recent work has focused on the question as to what kind of organizational culture promotes the development of organizational systems, and processes [21]. Wang and Rafiq [19] suggested shared vision and organizational diversity as the main elements that constitute an ambidextrous organizational culture. On the one side, Gibson and Birkinshaw [10] highlighted that shared vision was a transformational mechanism that encourages and inspires the active involvement of employees in the organizational management process, as well as the integrative judgments of individuals. On the other side, Rink and Ellemers [39] hold that organizational diversity was defined as the set of organizational values and norms that respect and tolerate differences in knowledge and viewpoints. Combined with specific Chinese context, $\mathrm{Xu}$ et al. [40] transferred the shared vision and organizational diversity to an adaptive and consistent culture. In line with Han et al. [41], the group with ambidextrous organizational culture (i.e., adaptive and consistent culture) emphasized the individual subjectivity to make choices and to develop themselves, and allowed the task-related differences to be congruent with the organizational norms. According to Junni et al. [42] and Lee et al. [43], the ambidextrous organizational culture have shown positive effects on the organizational performance. Furthermore, such ambidextrous culture constructed by the adaptive culture and consistent culture or shared vision and organizational diversity, was regarded as a causal organizational resource for organizational outcomes [10,19,41].

\subsection{Ambidexterity in Construction Projects}

A construction project is formed from numerous organizations. Individuals or groups originating from their parent companies or different organizations congregate for a specific project task and the project-based organization is disbanded upon the completion of the project task. According to Giritli and Oraz [44], the project-based character of a construction project within the temporary organization, will influence the managerial leadership styles or behaviors of professionals working in the construction projects. Although, there are different preferences for leadership styles, it may not be the most effective or successful leadership to consider all project conditions. For example, Cleland [45] stated that leadership is a continuous and flexible process, thus leadership in terms of project needs has to be adapted to the project's particular situation. Moreover, Naum [46] argued that projects coupled with large capital investment and complex decision-making, usually require different leadership styles. Moreover, according to Harvey and Ashworth [47], the construction projects have some specific characteristics, such as the project life-cycle and contractual arrangements, which have to be taken into account. The success of construction projects is associated with the leadership of project managers [48]. Furthermore, the managers or professionals of construction projects need different leadership styles or behaviors which should be adapted to different phases of the life cycle. Different leadership styles will change in the same pace as the progress of the construction projects [44]. The difference in task requirements among different project stages also suggests that different leadership styles may be adopted for each stage [49]. To sum up, it is difficult to identify the most appropriate leadership style 
in a construction project. As such, leadership in projects may switch from one style of leadership to another or combine different leadership styles. Individuals involved in the implementation and management process of construction projects cannot rely on or exert a single leadership style but enact a range of leadership styles to reach a right balance. Similarly, when it comes to the culture for construction projects, the different climate or values taken from different stakeholders were integrated in the project-based organization. Therefore, the ambidextrous organizational culture combined with the different existing cultures was regarded from a general standpoint rather than from a singular one for construction projects.

According to the ambidexterity theory of leadership and culture, the above-mentioned structure of leadership and culture in theories would be used in the literature and analysis. Prior research has provided evidence indicating that ambidextrous leadership could be formed by combining transformational and transactional leadership [14,50], and ambidextrous culture could be consisting of adaptive and consistent culture [40,41]. While organizational ambidexterity could occur at all hierarchical levels of an organization [51], it could also occur at the project level. Hence, the ambidextrous leadership and ambidextrous organizational culture would be used in this study to explore and explain the mechanism through which leadership and culture boost the performance of project-based organizations as well as enable the sustainable development of construction projects.

\subsection{Ambidextrous Leadership and Sustainability-Based Project Performance}

Leadership has been proved to be a positive force in the construction innovation context. More specifically it plays an important role at the firm level. For example, Staniewski et al. [52] suggested that a strong leadership and a highly qualified educated manager would contribute to the innovative activity of construction enterprises. The majority of researchers referred to transformational leadership and transactional leadership as the core effective leadership behavior in organizations. Avolio et al. [53] identified the main four components of transformational leadership, namely idealized influence, inspirational motivation, intellectual stimulation, and individualized consideration. Bass [15] and Bycio et al. [54] labeled the core components of transactional leadership, including management by exception and contingent reward.

As expected, different leadership behaviors have different effects [55]. Podsakoff et al. [56] indicated that transformational leadership had an active effect on organizational performance. Bass [57] disclosed that transformational leadership was found to be highly correlated with outcomes in subordinates' and unit effectiveness. Mao and Long [58] proved that transformational leadership positively and significantly predicted organizational performance. Brandt et al. [59] reported that transformational leaders could stimulate organizational members to anticipate changes of the external environment and to adapt to them in order to improve the organizational profitability. Besides, there was also empirical evidence suggesting the role of transactional leadership. Politis [60] suggested that transactional leadership has an indirect effect on organizational performance. Moreover, Chan et al. [55] found that transactional leadership has a negative effect on fostering construction innovation at the firm level. Zheng et al. [61] showed that transactional leadership positively affects organizational innovation performance in a project-based organization setting.

Ambidextrous leadership is formed by two complementary sets of leadership behaviors that fit the organizational and environmental requirements [25]. The most important characteristics of the ambidextrous leadership are flexibility and fluidity so that leaders can switch between two leadership behaviors as required by the organizational task. Liu and Fang [62] established a power-based leadership behavioral model and stressed that project leaders' behaviors or styles exert a significant influence on the performance of project team members. The contradicting leadership styles may pose a synergistic influence on fostering the organization whole effect [63].

Thus, we propose the following hypotheses and sub-hypotheses: 
Hypothesis 1. Ambidextrous leadership has a significant direct effect on sustainability-based project performance.

Hypothesis 1a. Transformational leadership has a significant direct effect on sustainability-based project performance.

Hypothesis 1b. Transactional leadership has a significant direct effect on sustainability-based project performance.

Hypothesis 1c. Transformational leadership and transactional leadership have an interaction effect on sustainability-based project performance.

Hypothesis 1d. The ambidextrous leadership integrated from transformational leadership and transactional leadership has a positive significant effect on sustainability-based project performance.

\subsection{Ambidextrous Leadership and Project Ambidextrous Culture}

Dension and Mishra [20] suggested that an involving and adapting culture could emphasize flexibility and changes in the environment, while a consistent culture ensured stability and direction. Thus, the organizational culture could be developed as a solution for solving the dual problems of external adaptation and internal integration $[38,41]$. The organizational ambidextrous culture has been defined as adaptive culture and consistent culture according to the connotation of contextual ambidexterity [40]. Mccarthy and Gordon [64] suggested that a team with ambidextrous culture pays attention to the employees, encourages the decision making and allocates time spontaneously.

Moreover, according to the social cognitive theory [65], people are producers that operate through phenomenal and functional consciousness, rather than passively coping with the external environment. The behaviors of executives or managers is crucial to supporting the organizational or team culture to make the leaders' behaviors visible or effective [66]. Thus, there is a close relationship between the organizational culture and the leaders' behaviors or styles. Considering the above statement, ambidextrous leadership is not a single leader or leader behavior, but is rather shared across many hierarchical management levels. Ambidextrous leadership could execute transformational behaviors (e.g., provide a vision) to obtain the identification and support of employees, and adopt transactional behaviors (e.g., personnel training, performance appraisal and reward systems) to manage conflicts and contradictions and guarantee the organizational order and consistency [67].

Hence, ambidextrous leadership is conductive for fostering an ambidextrous culture. Transformational leadership encourages employees to work and cooperate together to achieve the mutual vision or goal. The followers in the organization are more likely to identify with the collective vision and perceive the goals as their own [68]. In addition, transactional leadership could have a higher potential to associate with the perceptions of organizational support and justice [69]. Contingent reward and active management-by-exception would be perceived by employees as fair to follow the criterion or discipline of the organization. Therefore, we hypothesize:

Hypothesis 2. Ambidextrous leadership is positively related to project ambidextrous culture.

Hypothesis 2a. Transformational leadership is positively related to project adaptive culture.

Hypothesis $\mathbf{2 b}$. Transactional leadership is positively related to project consistent culture.

Hypothesis 2c. Ambidextrous leadership integrated from transformational leadership and transactional leadership has a positive significant effect on ambidextrous culture formed by adaptive culture and consistent culture.

\subsection{Project Ambidextrous Culture and Project Performance}

As outlined above, the ambidextrous culture formed from an adaptive and consistent culture, might well fit within the project-based organization demands. The adaptive culture in the organization emphasizes quick responses and answers for the external environment and new domains. Though, it is 
difficult to cope with the new knowledge or technological issues in the project, or to integrate across stakeholders from different organization units [70]. Moreover, the adaptive culture encourages the organizational diversity to tolerate differences and changes, advocating individuals' different viewpoints and behaviors to break the convention [71].

The consistent culture in the organization emphasizes the shared vision, which could be taken as the organizational values and norms, to facilitate the positive and active participation of organizational members in the process of goal achievement, communication, cooperation, and knowledge sharing [19,72]. Besides, the consistent culture is beneficial to reduce the uncertainty of the task and to maintain the existing norms to improve the organizational harmony [73].

Overall, in the organization with ambidextrous culture, each member plays the dual roles of differentiation supporter and resource integrator [41]. The heterogeneous knowledge and perspective, and the harmonious interaction among members could promote the improvement of organizational performance. Thus, we hypothesize:

Hypothesis 3. Project ambidextrous culture is positively related to sustainability-based project performance.

Hypothesis 3a. Adaptive culture is positively related to sustainability-based project performance.

Hypothesis $3 \mathbf{b}$. Consistent culture is positively related to sustainability-based project performance.

Hypothesis 3c. Ambidextrous culture integrated from adaptive culture and consistent culture has a positive significant effect on sustainability-based project performance.

\subsection{The Mediation Effects of Project Ambidextrous Culture}

Within this paper, we have proposed that ambidextrous leadership is positively associated with sustainability-based project performance (Hypothesis 1). We have also argued that ambidextrous leadership likely has a positive effect on ambidextrous culture (Hypothesis 2). In addition, we have hypothesized that a positive relationship between ambidextrous culture and sustainability-based project performance exists (Hypothesis 3). By extension, the theorizing behind Hypotheses 1-3 also suggests a mediation model that explains the indirect effect of ambidextrous leadership on sustainability-based project performance via ambidextrous culture. By integrating the above arguments, it suggests that the effect of ambidextrous leadership on project performance will be mediated by the ambidextrous culture in the project implementation and management process. Therefore, we hypothesize:

Hypothesis 4. Project ambidextrous culture mediates the relationship between ambidextrous leadership and sustainability-based project performance.

Hypothesis 4a. Adaptive culture mediates the relationship between transformational leadership and sustainability-based project performance.

Hypothesis $4 \mathbf{b}$. Consistent culture mediates the relationship between transactional leadership and sustainability-based project performance.

Hypothesis 4c. The ambidextrous culture formed by adaptive culture and consistent culture mediates the relationship between ambidextrous leadership, which is formed by transformational leadership and transactional leadership, and sustainability-based project performance.

In this study, ambidexterity is introduced into construction projects. Based on prior research and the above-mentioned hypotheses, a conceptual model was established as shown in Figure 1. First, we assess how ambidextrous leadership (composed by transformational leadership and 
transactional leadership) influences sustainability-based project performance (Hypothesis 1). Second, we assess how ambidextrous leadership is associated with the ambidextrous culture (consisted of adaptive culture and consistent culture) (Hypothesis 2). Third, we evaluate how ambidextrous culture influences sustainability-based project performance (Hypothesis 3), and finally, how ambidextrous culture exerts a mediating role (Hypothesis 4$)$.

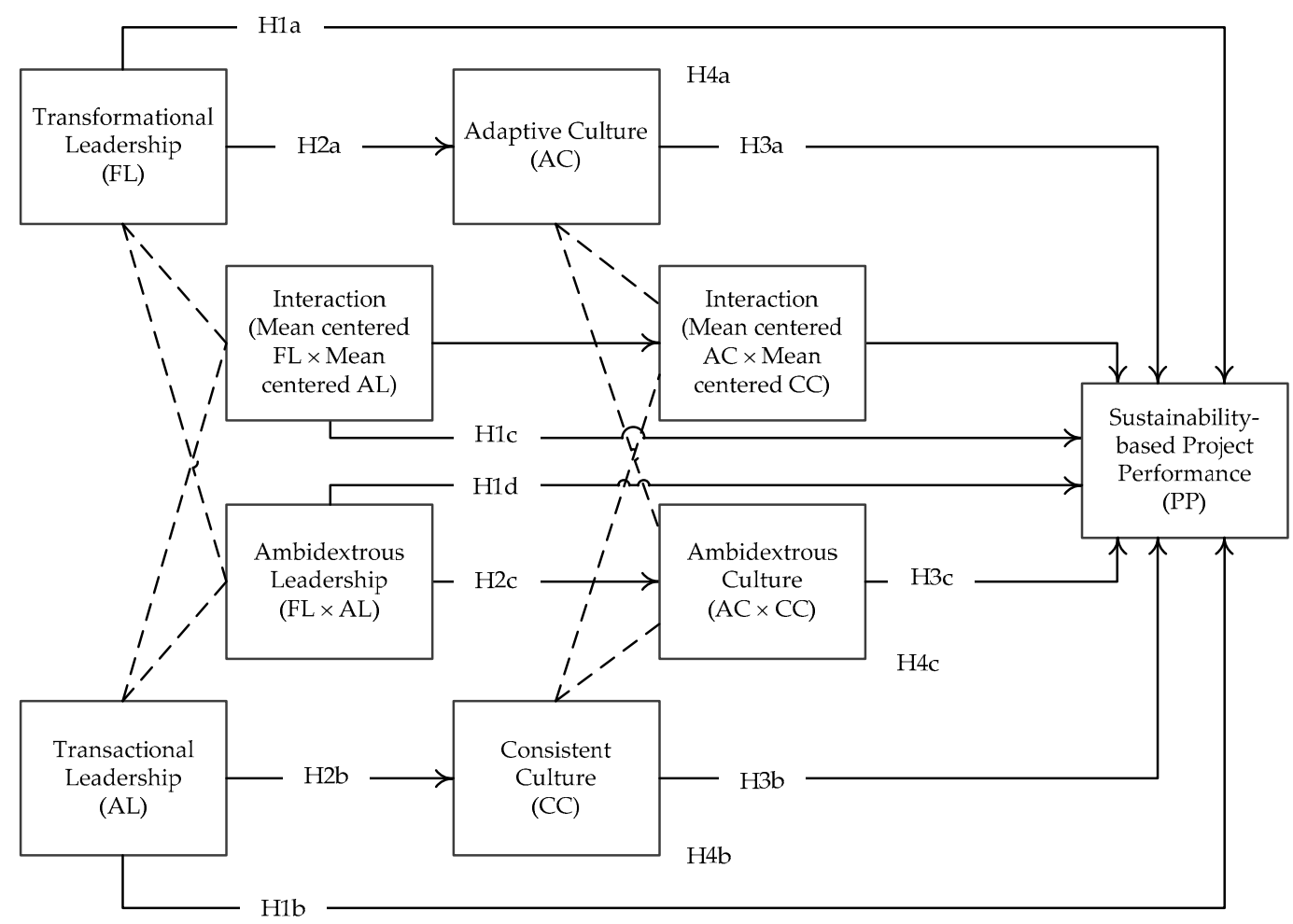

Figure 1. Conceptual model.

\section{Data and Methods}

\subsection{Participants and Procedures}

Survey questionnaires were distributed through on-line and e-mail to the members engaging in the construction projects operated in China. The respondents were selected on the basis of research purpose with the selection criteria tailored to the specific research target [74]. All respondents were project managers or engineers or subordinates taking part in various types of construction projects, including building projects, highway projects, and railway projects. Using managers or engineers or members of the project team as the source of data for the project-level variables is appropriate given that the sample is formed from executors who could improve and promote the project performance. Two different forms of questionnaires labeled as Form-A, and Form-B were prepared. Form-A collected the data concerning the context of the project and the individual conditions, which were partially taken as control variables. Form-B asked the respondents to evaluate the scales of the research variables. Out of 300 distributed questionnaires, 260 questionnaires were returned. After excluding the incomplete questionnaires and the identical answers, the final usable sample contained 217 data. Table 1 depicts the characteristics of the respondents. 
Table 1. Characteristics of the sample.

\begin{tabular}{cccc}
\hline Variables & Frequency & Variables & Frequency \\
\hline Education & \multicolumn{3}{c}{ Gender } \\
Under junior college & 3 & Male & 82 \\
Junior college & 23 & Female & 135 \\
Bachelor & 81 & Job & \\
Master & 88 & General employee & 71 \\
Ph.D. and above & 22 & Technician/Engineer & 70 \\
Working, years & & Junior manager & 42 \\
$\leq 5$ & 110 & Middle manager & 29 \\
$6-10$ & 75 & Senior manager & 5 \\
$11-15$ & 18 & & \\
$16-20$ & 5 & & 217 \\
$\geq 20$ & 9 & Total & \\
\hline
\end{tabular}

\subsection{Measures}

The project-level variables, such as ambidextrous leadership, project ambidextrous culture, sustainability-based project performance, were measured. The 5-point Likert-type scale was used for all studied variables, the format of which was anchored as $1=$ strongly disagree and $5=$ strongly agree. Meanwhile, other variables, such as gender, education, working years, working unit, and project type were taken as the control variables in the questionnaire.

\subsubsection{Ambidextrous Leadership}

In this study, the ambidextrous leadership was calculated by the product of transformational leadership and transactional leadership, according to the practice of Cao et al. [75]. The 5-items scale of transformational leadership, validated by prior studies such as Li and Shi [76] and Chen et al. [77], considered several dimensions, namely intellectual simulation, inspirational motivation, vision inspiration and moral modeling. The Cronbach's $\alpha$ was 0.875 . The 4 -items scale of transactional leadership was developed by Waldman et al. [78] and Yang et al. [79] with two dimension of contingency reward and exception by management. The Cronbach's $\alpha$ was 0.774 .

\subsubsection{Project Ambidextrous Culture}

The 11-item short-form of two dimensional scale was adopted to the dimensions of adaptive culture ( 6 items) and consistent culture (5 items) as developed by Xu et al. [40]. The ambidextrous culture of the project could also be calculated by the product of adaptive culture and consistent culture. The interaction of the two kinds of culture cannot be the representative of the ambidextrous culture but rather the additional influence when the two cultures coexisted [41]. The Cronbach's alpha of the adaptive culture scale was 0.904 , as that of the consistent culture was 0.864 .

\subsubsection{Sustainability-Based Project Performance}

The sustainability-based 0 project performance was evaluated by the project managers and project team members with a 5-item scale according to Ozorhon et al. [80]. The Cronbach's alpha was 0.899.

\subsubsection{Control Variables}

Gender, education, working years and jobs were considered as control variables in this study. The categorical question ( $1=$ male and $0=$ female) was used to assess gender. Education was measured by a 5-point scale from 1 (under junior college) to 5 (Ph.D. and above), while working years were measured by a 5-point scale ranging from 1 ( $\leq 5$ years) and 5 ( $\geq 20$ years). Last, the job was measured by a 5 -point scale ranging from 1 (general employee) to 5 (senior manager). 
An exploratory factor analysis (principle components analysis with maximum varimax rotation) was conducted to identify the dimension of variables. Factor loading of more than 0.40 was considered as a criterion to retain items, as shown in Table 2. The Cronbach's alpha, composite reliability (CR) and average variance extraction (AVE) were also depicted in Table 2. The $\alpha$ and CR above 0.70 were consider as a criterion [81], and the AVE above 0.50 was also considered as a criterion [82]. The statistics of the study variables almost meet these criteria.

Table 2. Results of exploratory factor analysis.

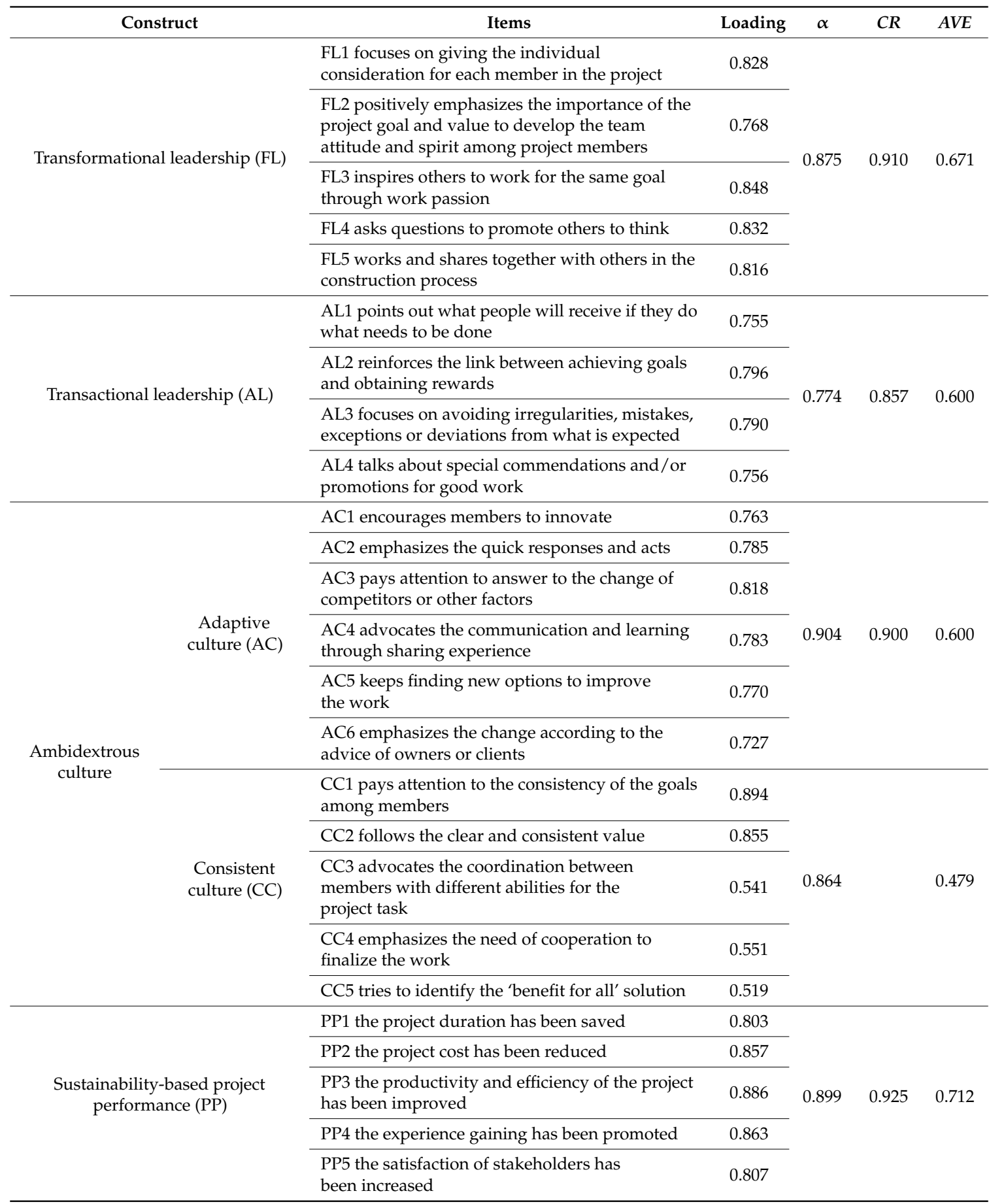




\subsection{Analytic Strategy}

After the measurement models analysis (e.g., reliability test and validity test), given the mediation conceptual framework, the direct and indirect effects of hypotheses were respectively tested using Linear Regression methods through the software Stata 13.0 with the Baron and Kenny approach [83]. The test results showed the significance of regression coefficients indicating the significant of the influence path, and the coefficient of determination $\mathrm{R}$ square indicating the explained variance percentage. Moreover, the mediating effects of the total model were applied Structural Equation Modeling (SEM) analyses through the software AMOS 24.0 with the bootstrapping method [84]. The test results showed the confidence intervals, which were better than the significance of coefficients. Finally, in order to test whether the effects of ambidextrous leadership and ambidextrous culture were significantly better than the single leadership or culture, the within-group ANOVA technique was used with the software SPSS 22.0 to justify the significance of different groups.

Specifically, prior to testing these hypotheses, we conducted common method variance test, reliability test, confirmatory factor analysis (CFA) and correlation analysis to test all the study variables. Next, Hypothesis 1-3 were tested using multiple regression analysis, and the $p$-value and R square were adopted to judge the significance of coefficients and the goodness of the regression model. Hypothesis 4 was tested using the structural equation modeling. The mediation models were tested with the method of bootstrapping. The 95\% confidence interval around the total, direct and indirect effects were constructed using bootstrapping approaches with 1000 iterations. Lastly, the variance analysis was used to analyze the within-group difference using ANOVA. According to the scales of the sample data, the sample was divided into four groups to be compared with the mean difference of each group.

\section{Results}

\subsection{Common Method Variance Test}

The dependent and independent variables were measured in the same questionnaire, thus it was necessary to conduct a common method variance test. Firstly, the Harman's one-factor test was conducted [85], whereby all items were simultaneously entered into a factor analysis through principle components analysis and maximum varimax rotation. The results of the factor analysis indicated that four factors explaining $64.812 \%$ of the variance, with the first factor accounting for $20.401 \%$ of the total variance. The results suggest that there was not a single factor structure that all items emerged, or one factor that accounted for the majority of the total variance.

Secondly, the alternative testing approach was implemented as suggested by Malhotra et al. [86]. The fit indices indicated that a hypothesized model consisting of a single latent variable had a poor fit, such as $\chi^{2} / d f=4.457 ; C F I=0.727 ; G F I=0.639 ; T L I=0.702 ; R M S E A=0.127$. Therefore, the common methods bias is not a serious problem for the data in this study.

\subsection{Reliability and Validity Test}

The reliability results have been stated in Table 2. The Cronbach's alpha and the composite reliability of all studied variables met the criterion, and results which were in line with previous studies. Besides, the results of the exploratory factor analysis have also been exposed in Table 2, indicating the construct validity of the studied variables. Meanwhile, the average variance extraction (AVE) values of all studied variables have been calculated, the results of which either exceeded 0.500 or were close to 0.500 . The factor loadings of all the items were more than 0.500 . These results indicated that there was a good convergent validity. Table 3 shows the discriminant validity through confirmatory factor analysis using AMOS 24.0 version. Compared with the competitive model, the fit indices of five factors model were better, which indicated that the scales have a good discriminant validity. 
Table 3. Results of confirmatory factor analysis.

\begin{tabular}{|c|c|c|c|c|c|c|}
\hline Model & $x^{2}$ & $d f$ & $\chi^{2} / d f$ & $C F I$ & $T L I$ & RMSEA \\
\hline 5 factors model: FL, AL, AC, CC, PP & 588.368 & 265 & 2.220 & 0.907 & 0.895 & 0.075 \\
\hline $\begin{array}{l}4 \text { factors model: leadership variables (combined: FL } \\
\text { and } A L), A C, C C, P P\end{array}$ & 623.317 & 269 & 2.317 & 0.898 & 0.886 & 0.078 \\
\hline $\begin{array}{l}3 \text { factors model: leadership variables (combined: FL } \\
\text { and } A L) \text {, culture variables (combined: } A C, C C), P P\end{array}$ & 736.605 & 272 & 2.708 & 0.866 & 0.853 & 0.089 \\
\hline $\begin{array}{l}2 \text { factors model: leadership variables (combined: FL } \\
\text { and } A L \text { ), and PP combined AC with CC }\end{array}$ & 1019.241 & 274 & 3.720 & 0.786 & 0.765 & 0.112 \\
\hline 1 factor model: all items loading on the same factor & 1225.571 & 275 & 4.457 & 0.727 & 0.702 & 0.127 \\
\hline
\end{tabular}

Notes: Sample size $=217$; FL, transformational leadership; AL, transactional leadership; AC, adaptive culture; CC, consistent culture; PP, sustainability-based project performance. Model fit was assessed using the recommended cut-offs: 0.90 for TLI (Tucker-Lewis index) [87] and CFI (comparative fit index) [88]; 0.05 as an indicator of good fit and 0.10 as the upper limit of acceptable fit for RMSEA (root mean square error of approximation) [89].

\subsection{Descriptive Analysis and Correlation Analysis}

Table 4 shows the mean, standard deviation, and Pearson correlation coefficients of all studied variables. In line with previous research, transformational leadership and transactional leadership had positive associations with project ambidextrous culture dimensions and project performance. Furthermore, the adaptive culture and consistent culture also had positive relationships with project performance. Besides, the square root values of AVE in parentheses were almost exceeded the correlation coefficients, which further confirmed the discriminant validity.

Table 4. Descriptive statistics and correlation coefficients.

\begin{tabular}{lccccccccc}
\hline \multicolumn{1}{c}{ Variables } & $\mathbf{1}$ & $\mathbf{2}$ & $\mathbf{3}$ & $\mathbf{4}$ & $\mathbf{5}$ & $\mathbf{6}$ & $\mathbf{7}$ & $\mathbf{8}$ & $\mathbf{9}$ \\
\hline Mean & - & 3.470 & 1.750 & 2.203 & 3.734 & 3.664 & 3.719 & 3.801 & 3.737 \\
s.d. & - & 0.866 & 0.998 & 1.108 & 0.933 & 0.868 & 0.920 & 0.868 & 0.887 \\
1. Gender & - & & & & & & & & \\
2. Education & $0.153^{*}$ & - & & & & & & & \\
3. Working years & 0.088 & $-0.182^{* *}$ & - & & & & & & \\
4. Job & $0.177^{* *}$ & 0.058 & $0.411^{* *}$ & - & & & & & \\
5. FL & -0.088 & -0.098 & -0.023 & 0.028 & $(0.819)$ & & & & \\
6.AL & -0.037 & -0.051 & -0.003 & -0.024 & $0.692^{* *}$ & $(0.775)$ & & & \\
7. AC & -0.068 & $-0.157^{*}$ & 0.006 & -0.044 & $0.681^{* *}$ & $0.639^{* *}$ & $(0.775)$ & & \\
8. CC & -0.056 & $-0.147^{*}$ & -0.047 & 0.009 & $0.574^{* *}$ & $0.551^{* *}$ & $0.703^{* *}$ & $(0.692)$ & \\
9. PP & 0.052 & -0.047 & 0.077 & 0.019 & $0.505^{* *}$ & $0.475^{* *}$ & $0.595^{* *}$ & $0.605^{* *}$ & $(0.844)$ \\
\hline
\end{tabular}

Notes: Sample size = 217. s.d., standard deviation; FL, transformational leadership; AL, transactional leadership; $\mathrm{AC}$, adaptive culture; $\mathrm{CC}$, consistent culture; $\mathrm{PP}$, sustainability-based project performance. The values in parentheses are the square root of AVE. ${ }^{*} p<0.05 ;{ }^{* *} p<0.01$. Tow-tailed test.

In addition, the control variables, except education, were not significantly correlated to the studied variables. If the control variables had little or no influence on the outcome variable, it was better not to include the control variables in the regression model [90]. Finally, the recommendation was followed and control variables, such as gender, working years and job (excluding education), were included in the following analysis.

\subsection{Hypothesis Testing}

To test the proposed hypotheses, the data was analyzed using a series of regression analyses.

\subsubsection{The Main Effect of Ambidextrous Leadership on Project Performance}

As shown in Table 5, the main effect of transformational leadership on sustainability-based project performance was positive and statistically significant $(\beta=0.517, p<0.001$, Model 1$)$. This yields 
support for Hypothesis 1a. The main effect of transactional leadership on sustainability-based project performance was positive and statistically significant $(\beta=0.477, p<0.001$, Model 2$)$, which yields support for Hypothesis $1 \mathrm{~b}$. To test Hypothesis $1 \mathrm{c}$ predicting the coordination effect of transformational leadership and transactional leadership on sustainability-based project performance, we computed the centering interaction of two leadership styles to be included in the equation model, as seen in Model 3. The results reveal that the coordination effect of transformational leadership and transactional leadership on sustainability-based project performance was positive and statistically significant $\left(\beta_{\mathrm{FL} \times \mathrm{AL}}=0.130, p<0.05\right)$, with the weaken significant effects of transformational leadership $(\beta=0.385$, $p<0.001)$ and transactional leadership $(\beta=0.250, p<0.01)$. This suggests that the relationship between transformational leadership and sustainability-based project performance would be amplified under the increasing influence of transactional leadership. What is more, the relationship between transactional leadership and sustainability-based project performance would be simultaneously strengthened under the increasing influence of transformational leadership. This provides support for Hypothesis 1c.

Table 5. Regression results before the ambidextrous variables integrated.

\begin{tabular}{|c|c|c|c|c|c|c|c|c|c|c|}
\hline \multirow[t]{2}{*}{ Variables } & \multicolumn{3}{|c|}{$\begin{array}{l}\text { Sustainable-Based } \\
\text { Project Performance } \\
\text { (Dependent Variable) }\end{array}$} & \multirow{2}{*}{$\begin{array}{c}\begin{array}{c}\text { Adaptive } \\
\text { Culture } \\
\text { (Mediator) }\end{array} \\
\text { Model } 4 \\
\end{array}$} & \multirow{2}{*}{$\begin{array}{c}\begin{array}{c}\text { Consistent } \\
\text { Culture } \\
\text { (Mediator) }\end{array} \\
\text { Model } 5\end{array}$} & \multicolumn{5}{|c|}{$\begin{array}{l}\text { Sustainable-Based Project Performance } \\
\text { (Dependent Variable) }\end{array}$} \\
\hline & Model 1 & Model 2 & Model 3 & & & Model 6 & Model 7 & Model 8 & Model 9 & Model 10 \\
\hline \multicolumn{11}{|c|}{ Control variables } \\
\hline gender & 0.099 & 0.065 & 0.095 & 0.003 & -0.040 & 0.087 & 0.085 & $0.106^{*}$ & 0.097 & 0.086 \\
\hline years & 0.103 & 0.078 & 0.074 & 0.058 & -0.065 & 0.065 & 0.120 * & 0.067 & 0.077 & 0.111 \\
\hline job & -0.056 & -0.014 & -0.034 & -0.087 & 0.056 & 0.003 & -0.051 & -0.013 & -0.015 & -0.042 \\
\hline \multicolumn{11}{|c|}{ Independent variables } \\
\hline FL & $0.517^{* * *}$ & & $0.385^{* * *}$ & $0.685^{* * *}$ & & & & & $0.199 * *$ & \\
\hline $\mathrm{AL}$ & & $0.477^{* * *}$ & $0.250 * *$ & & $0.551^{* * *}$ & & & & & $0.199 * *$ \\
\hline \multicolumn{11}{|c|}{ Mediators } \\
\hline $\mathrm{AC}$ & & & & & & $0.600 * * *$ & & $0.344 * * *$ & $0.464 * * *$ & \\
\hline $\mathrm{CC}$ & & & & & & & $0.616^{* * *}$ & $0.426^{* * *}$ & & $0.506^{* * *}$ \\
\hline \multicolumn{11}{|c|}{ Interactions } \\
\hline $\mathrm{FL} \times \mathrm{AL}$ & & & $0.130 *$ & & & & & & & \\
\hline $\mathrm{AC} \times \mathrm{CC}$ & & & & & & & & $0.155^{* *}$ & & \\
\hline$R^{2}$ & 0.273 & 0.236 & 0.315 & 0.471 & 0.309 & 0.366 & 0.385 & 0.460 & 0.387 & 0.412 \\
\hline$F$ & $19.92 * * *$ & $16.35^{* * *}$ & $16.13^{* * *}$ & $47.11 * * *$ & $23.72 * * *$ & $30.66^{* * *}$ & $33.17^{* * *}$ & $29.77^{* * *}$ & $26.69 * * *$ & $29.61 * * *$ \\
\hline
\end{tabular}

Notes: Sample size $=217$. Normalized beta coefficients indicated in the table. FL, transformational leadership; $\mathrm{AL}$, transactional leadership; AC, adaptive culture; CC, consistent culture. ${ }^{* * *} p<0.001,{ }^{* *} p<0.01,{ }^{*} p<0.05$.

\subsubsection{The Mediating Effect of Cultures between Leadership and Project Performance}

Hypothesis $2 \mathrm{a}$ and $2 \mathrm{~b}$ predicted that the effects of two leadership styles on two cultures. The regression analysis results reported in Model 4 of Table 5 supported Hypothesis 2a, revealing a significant effect of transformational leadership on the adaptive culture $(\beta=0.685, p<0.001)$. Meanwhile, the results reported in Model 5 of Table 5 supported Hypothesis $2 b$, indicating that a significant effect of transactional leadership on the consistent culture $(\beta=0.551, p<0.001)$.

In terms of Hypotheses 3a and 3b, as shown by Model 6 and Model 7 in Table 5, the direct impact of the adaptive culture on sustainability-based project performance was statistically significant $(\beta=0.600, p<0.001)$. Thus, Hypothesis $3 a$ was supported. The results also indicate that the direct impact of the consistent culture on sustainability-based project performance was statistically significant $(\beta=0.616, p<0.001)$. Hence, Hypothesis $3 \mathrm{~b}$ was supported. Besides, the results of Model 8 in Table 5 also reveal a significant coordination effect of adaptive culture and consistent culture on sustainability-based project performance $\left(\beta_{\mathrm{AC} \times \mathrm{CC}}=0.155, p<0.01\right)$ with the interaction of two cultures after centralization, provided that the relationship between the adaptive culture and sustainability-based project performance would be heightened with the growing consistent culture, and the relationship between the consistent culture and sustainability-based project performance would be enhanced under the condition of increasing adaptive culture. 
Hypothesis 4a highlights the indirect effect of the adaptive culture between transformational leadership and project performance. Combined with the two paths, transformational leadership $\rightarrow$ sustainability-based project performance $(\beta=0.517, p<0.001$, Model 1$)$, and transformational leadership $\rightarrow$ adaptive culture $(\beta=0.685, p<0.001$, Model 4$)$, the results reported in Model 9 in Table 5 reveal that the significant effect of transformational leadership on sustainability-based project performance $\left(\beta_{\mathrm{FL}}=0.199, p<0.01\right)$ was weakened through the significant effect of adaptive culture $\left(\beta_{\mathrm{AC}}=0.464, p<0.001\right)$. Thus, Hypothesis $4 \mathrm{a}$ was partially supported. Additionally, Hypothesis $4 \mathrm{~b}$ stated the indirect impact of consistent culture between transactional leadership and project performance. We also estimated the mediation effect as a product of three paths, transactional leadership $\rightarrow$ sustainability-based project performance $(\beta=0.477, p<0.001$, Model 2$)$, transactional leadership $\rightarrow$ consistent culture $(\beta=0.551, p<0.001$, Model 5$)$, and transactional leadership $\rightarrow$ consistent culture $\rightarrow$ sustainability-based project performance $\left(\beta_{\mathrm{AL}}=0.199, p<0.01 ; \beta_{\mathrm{CC}}=0.506\right.$, $p<0.001$, Model 10), which yields partial support for Hypothesis $4 \mathrm{~b}$.

The mediation effects were tested using confidence interval with the method of Structural Equation Modeling (SEM) and Bootstrapping techniques through the software AMOS 24.0 version. The advantage of SEM is that it tests the whole model, including the direct effect and indirect effect. As shown in Figure 2a and Table 6, the results of the partial mediation model indicated that the estimation of the direct effects of transformational leadership and transactional leadership on project performance were non-significant $\left(\beta_{\mathrm{FL}}=0.113,95 \% \mathrm{BC} \mathrm{CI}[-0.395 ; 0.676], 95 \%\right.$ PC CI $[-0.415 ; 0.620]$, containing zero; $\beta_{\mathrm{AL}}=-0.048,95 \%$ BC CI [ $\left.-0.742 ; 0.503\right], 95 \%$ PC CI [-0.699; 0.544], containing zero). It should be noted that the direct effects of transformational leadership and transactional leadership on project performance remained non-significant when both mediators were included in the model. Thus, we conducted the total mediation model, as shown in Figure $2 b$ and Table 6. An estimate of the indirect effects of transformational leadership and transactional leadership on project performance were positive and statistically significant $\left(\beta_{\mathrm{FL}-\mathrm{AC}-\mathrm{PP}}=0.228,95 \%\right.$ BC CI $[0.088 ; 0.381]$, $95 \%$ PC CI $[0.084 ; 0.378]$, not containing zero; $\beta_{\text {AL-CC-PP }}=0.242,95 \%$ BC CI $[0.078 ; 0.468], 95 \%$ PC CI $[0.058 ; 0.452]$, not containing zero). These results suggested that the adaptive culture and consistent culture totally mediated the effects of transformational leadership and transactional leadership on sustainability-based project performance when both mediators were in the model, which also provided the additional support for Hypothesis $4 \mathrm{a}$ and $4 \mathrm{~b}$.

Table 6. The results of mediation model through Bootstrap.

\begin{tabular}{|c|c|c|c|c|c|c|c|}
\hline \multirow{3}{*}{ Model } & \multirow{3}{*}{ Variables } & \multirow{3}{*}{ Estimate } & \multirow{3}{*}{ Standard Errors } & \multicolumn{4}{|c|}{ Bootstrapping } \\
\hline & & & & \multicolumn{2}{|c|}{ Bias-Corrected $95 \%$ CI } & \multicolumn{2}{|c|}{ Percentile 95\% CI } \\
\hline & & & & Lower & Upper & Lower & Upper \\
\hline \multirow{9}{*}{ Model a } & \multicolumn{7}{|c|}{ Total effects } \\
\hline & $\mathrm{AL} \rightarrow \mathrm{PP}$ & 0.196 & 0.329 & -0.432 & 0.726 & -0.429 & 0.728 \\
\hline & $\mathrm{FL} \rightarrow \mathrm{PP}$ & 0.281 & 0.285 & -0.168 & 0.845 & -0.184 & 0.815 \\
\hline & \multicolumn{7}{|c|}{ Direct effects } \\
\hline & $\mathrm{AL} \rightarrow \mathrm{PP}$ & -0.039 & 0.351 & -0.742 & 0.503 & -0.699 & 0.544 \\
\hline & $\mathrm{FL} \rightarrow \mathrm{PP}$ & 0.082 & 0.292 & -0.395 & 0.676 & -0.415 & 0.620 \\
\hline & \multicolumn{7}{|c|}{ Indirect effects } \\
\hline & $\mathrm{AL} \rightarrow \mathrm{PP}$ & 0.235 & 0.108 & 0.062 & 0.487 & 0.043 & 0.453 \\
\hline & $\mathrm{FL} \rightarrow \mathrm{PP}$ & 0.199 & 0.090 & 0.041 & 0.400 & 0.028 & 0.379 \\
\hline \multirow{3}{*}{ Model b } & \multicolumn{7}{|c|}{ Total effects/Indirect effects } \\
\hline & $\mathrm{AL} \rightarrow \mathrm{PP}$ & 0.242 & 0.095 & 0.078 & 0.468 & 0.058 & 0.452 \\
\hline & $\mathrm{FL} \rightarrow \mathrm{PP}$ & 0.228 & 0.072 & 0.088 & 0.381 & 0.084 & 0.378 \\
\hline
\end{tabular}

Notes: Bootstrap $=1000.95 \%$ CI, 95\% Confidence interval; BC, Bias-Corrected; PC, Percentile; FL, transformational leadership; $\mathrm{AL}$, transactional leadership; $\mathrm{AC}$, adaptive culture; $\mathrm{CC}$, consistent culture; $\mathrm{PP}$, sustainability-based project performance. 


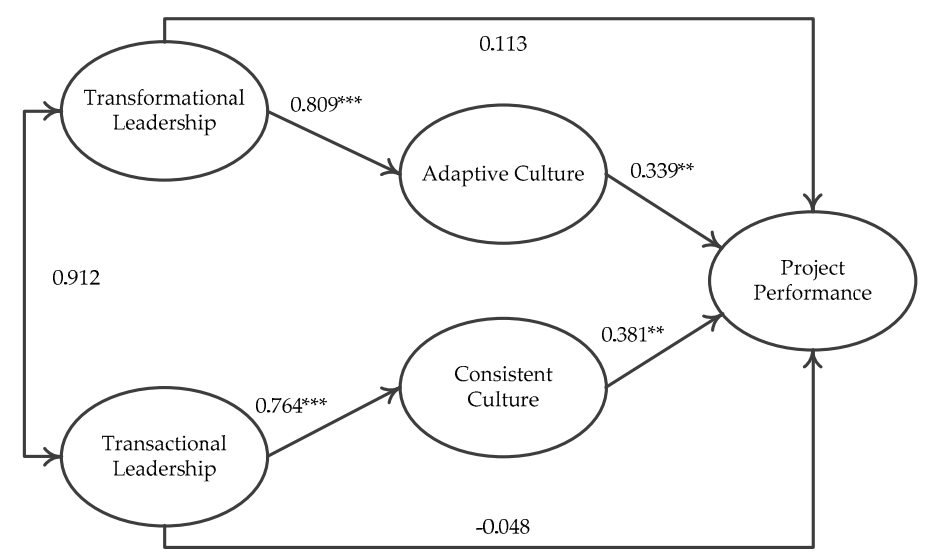

(a)

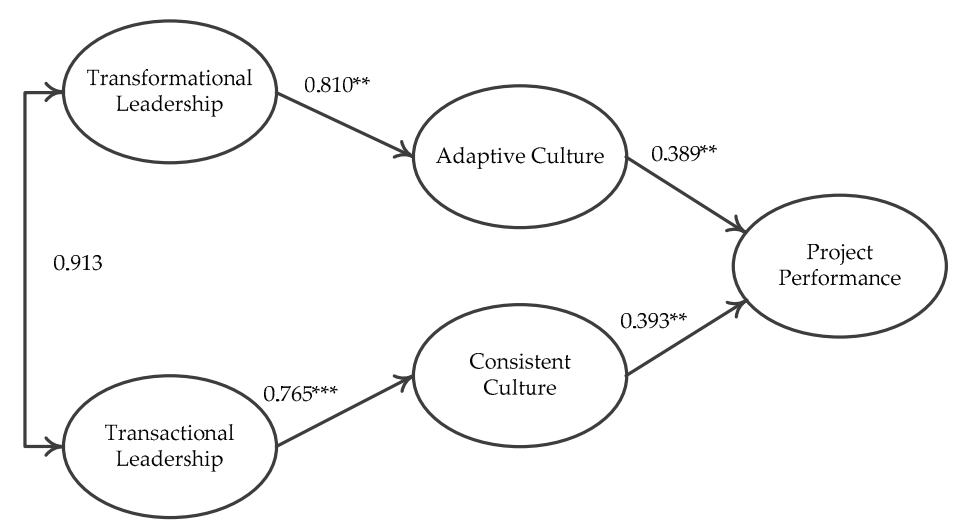

(b)

Figure 2. Mediation model: (a) Partial mediation model; (b) Total mediation model. Notes: The asterisk refers to the significance of the path coefficients. ${ }^{* *} p<0.001,{ }^{* *} p<0.01$.

\subsubsection{The Mediation Effect of Ambidextrous Culture}

The ambidextrous leadership was computed using the product of transformational leadership and transactional leadership, and the ambidextrous culture was also integrated by multiplying the adaptive culture and the consistent culture. After the single variable was combined with two variables, the direct effect of ambidextrous leadership and the indirect effect of ambidextrous culture were analyzed through multiple regression analysis, as shown in Table 7.

The main effect of ambidextrous leadership on sustainability-based project performance predicted in Hypothesis $1 \mathrm{~d}$ was statistically significant $(\beta=0.533, p<0.001$, Model 11$)$. To test Hypothesis $2 \mathrm{c}$ predicting that the effect of ambidextrous leadership on ambidextrous culture was positively significant ( $\beta=0.731, p<0.001$, Model 12). Meanwhile, the effect of ambidextrous culture on sustainability-based project performance was also statistically significant $(\beta=0.672, p<0.001$, Model 13), which yields support for Hypothesis 3c. In addition, to test Hypothesis $4 \mathrm{c}$ predicting the mediating effect of ambidextrous leadership on sustainability-based project performance via ambidextrous culture, after entering ambidextrous culture into the regression equation in which sustainability-based project performance was regressed on ambidextrous culture, the beta coefficients of ambidextrous leadership on sustainability-based project performance ( $\beta=0.533, p<0.001$, Model 11) turned to be not statistically significant $(\beta=0.133, p>0.05$, Model 14), and the path of ambidextrous culture on sustainability-based project performance was also statistically significant $(\beta=0.575, p<0.001$, Model 14). These results show that ambidextrous culture played a total mediator role in the relationship between ambidextrous leadership and sustainability-based project performance. Thus, Hypothesis $4 \mathrm{c}$ which indicated that ambidextrous culture will mediate the relationship between ambidextrous leadership and 
sustainability-based project performance was partially supported, and the result was in accordance with the bootstrapping results.

Table 7. Regression results after the ambidextrous variables integrated.

\begin{tabular}{ccccc}
\hline \multirow{2}{*}{ Variables } & $\begin{array}{c}\text { Sustainable-Based Project } \\
\text { Performance (Dependent Variable) }\end{array}$ & $\begin{array}{c}\text { Ambidextrous } \\
\text { Culture (Mediator) }\end{array}$ & \multicolumn{2}{c}{$\begin{array}{c}\text { Sustainable-Based Project } \\
\text { Performance (Dependent Variable) }\end{array}$} \\
\cline { 2 - 5 } & Model 11 & Model 12 & Model 13 & Model 14 \\
\hline $\begin{array}{c}\text { Control variables } \\
\text { gender } \\
\text { year } \\
\text { job }\end{array}$ & 0.091 & -0.027 & $0.104^{*}$ & $0.106^{*}$ \\
$\begin{array}{c}\text { Independent variable } \\
\text { Ambidextrous } \\
\text { Leadership }\end{array}$ & 0.076 & 0.012 & 0.068 & -0.015 \\
\hline $\begin{array}{c}\text { Mediator } \\
\text { Ambidextrous Culture }\end{array}$ & -0.031 & -0.029 & -0.011 & 0.133 \\
\hline $\begin{array}{c}R^{2} \\
F\end{array}$ & $0.553^{* * *}$ & $0.731^{* * *}$ & & $0.575^{* * *}$ \\
\hline
\end{tabular}

Notes: Sample size $=217$. Normalized beta coefficients indicated in the table. Ambidextrous leadership, transformational leadership $\times$ transactional leadership; Ambidextrous culture, adaptive culture $\times$ consistent culture. ${ }^{* * *} p<0.001,{ }^{*} p<0.05$.

4.4.4. The Variance Analysis of Different Groups with Ambidextrous Leadership or Ambidextrous Culture

In addition, to probe the advantage of ambidextrous leadership in the management process of construction projects, we conducted the variances homogeneity analysis and the intergroup variance analysis in the following four steps. (i) The median values of transformational leadership and transactional leadership were separately calculated as 4.000 and 3.750. (ii) The ambidextrous leadership could be divided into four groups according to the median values of two leadership styles. The group A1 was formed by the high transformational leadership (up from 4.000) and high transactional leadership (up from 3.750). Group B1 was composed of the low transformational leadership (down from 4.000) and high transactional leadership (up from 3.750). Group C1 was composed of the high transformational leadership (up from 4.000) and low transactional leadership (down from 3.750). Group D1 was composed of the low transformational leadership (down from 4.000) and low transactional leadership (down from 3.750), which indicates the group of no obvious leadership styles. (iii) The sustainability-based project performance of four groups was analyzed using the various homogeneity analysis, as shown in Table 8 . The results revealed that the value of Levene statistic was 7.263 but statistically significant $(p<0.001)$, suggesting that there is no variance homogeneity among the four groups of project performance. Thus, the method of Tamhane's T2 could be chosen to compute the intergroup variance analysis. (iv) As shown in Table 9, although the difference between group $\mathrm{A} 1$ and group $\mathrm{C} 1$ was not significant, there were significant mean differences between group A1 and group B1 $(0.749, p<0.001,95 \%$ CI $[0.259 ; 1.238])$, as well as group A1 and group D1 $(0.946, p<0.001,95 \%$ CI $[0.613 ; 1.279])$. Furthermore, compared with the mean values of the project performance from the four groups $\left(\right.$ Mean $_{A 1}=4.207 ;$ Mean $_{B 1}=3.461 ;$ Mean $_{C 1}=3.864$; Mean $\left._{D 1}=3.291\right)$ using $p$-value and confidence interval testing, there was also a significant mean difference between group C1 and group D1. Overall, the group with transformational leadership and/or transactional leadership could obtain better project performance, compared with that of no obvious leadership styles.

Table 8. Testing result of homogeneity of variances.

\begin{tabular}{cccc}
\hline Levene Statistic & $\boldsymbol{d} f_{\mathbf{1}}$ & $\boldsymbol{d} \boldsymbol{f}_{\mathbf{2}}$ & Sig. \\
\hline 7.263 & 3 & 213 & 0.000 \\
\hline
\end{tabular}


Table 9. Results of multiple comparisons using the method of Tamhane's T2.

\begin{tabular}{|c|c|c|c|c|c|c|}
\hline \multirow{2}{*}{ DV } & \multirow{2}{*}{ Group (1) } & \multirow{2}{*}{ Group (2) } & \multirow{2}{*}{$\begin{array}{c}\text { Mean } \\
\text { Difference }\end{array}$} & \multicolumn{2}{|c|}{$95 \%$ CI } & \multirow{2}{*}{ Results } \\
\hline & & & & Lower & Upper & \\
\hline \multirow{3}{*}{$\mathbf{P P}$} & \multirow{3}{*}{$\begin{array}{l}\text { Group A1 (High } \\
\text { FL \& High AL) }\end{array}$} & Group B1 (Low FL \& High AL) & $0.749^{* *}$ & 0.259 & 1.238 & Group A1 > Group B1 \\
\hline & & Group C1 (High FL \& Low AL) & 0.345 & -0.079 & 0.770 & non-significant \\
\hline & & Group D1 (Low FL \& Low AL) & $0.946^{* * *}$ & 0.613 & 1.279 & Group A1 > Group D1 \\
\hline \multirow{3}{*}{ PP } & \multirow{3}{*}{$\begin{array}{l}\text { Group A2 (High } \\
\text { AC \& High CC) }\end{array}$} & Group B2 (High AC \& Low CC) & $0.719^{* * *}$ & 0.357 & 1.082 & Group A2 > Group B2 \\
\hline & & Group C2 (Low AC \& High CC) & $0.717^{* * *}$ & 0.305 & 1.129 & Group A2 > Group C2 \\
\hline & & Group D2 (Low AC \& Low CC) & $1.247^{* * *}$ & 0.912 & 1.583 & Group A2 > Group D2 \\
\hline
\end{tabular}

Notes: Sample size $=217$. DV, Dependent variables; FL, transformational leadership; AL, transactional leadership; AC, adaptive culture; $\mathrm{CC}$, consistent culture; $\mathrm{PP}$, sustainability-based project performance; $95 \% \mathrm{CI}, 95 \%$ confidence interval. The method of Tamhane's T2 was used when equal variances not assumed. ${ }^{* * *} p<0.001,{ }^{* *} p<0.01$.

Continuing, the intergroup variances analysis was also employed for the effect of ambidextrous culture. The procedure was identical with the above analysis. The median of the adaptive culture was 3.830 and the median of the consistent culture was 4.000. According to the median values, the ambidextrous culture was divided into four groups, i.e., group A2 (high adaptive culture and high consistent culture), group B2 (high adaptive culture and low consistent culture), group C2 (low adaptive culture and high consistent culture), and group D2 (low adaptive culture and low consistent culture). As shown in Table 9, there were significant mean differences of project performance between group A2 and group B2 $(0.719, p<0.001,95 \%$ CI $[0.357 ; 1.082])$, group A2 and group C2 $(0.717, p<0.001$, 95\% CI [0.305; 1.129]), and group A2 and group D2 (1.247, $p<0.001,95 \%$ CI [0.912; 1.583]). Besides, there were also significant mean differences between the project performance of group B2 and that of group D2. The same was observed for the project performance of group C2 and that of group D2. Thus, adaptive culture and/or consistent culture partially improved the project performance compared with the group without ambidextrous culture.

In general, the results of hypothesis testing were summarized in Table 10.

Table 10. Results of hypothesis testing.

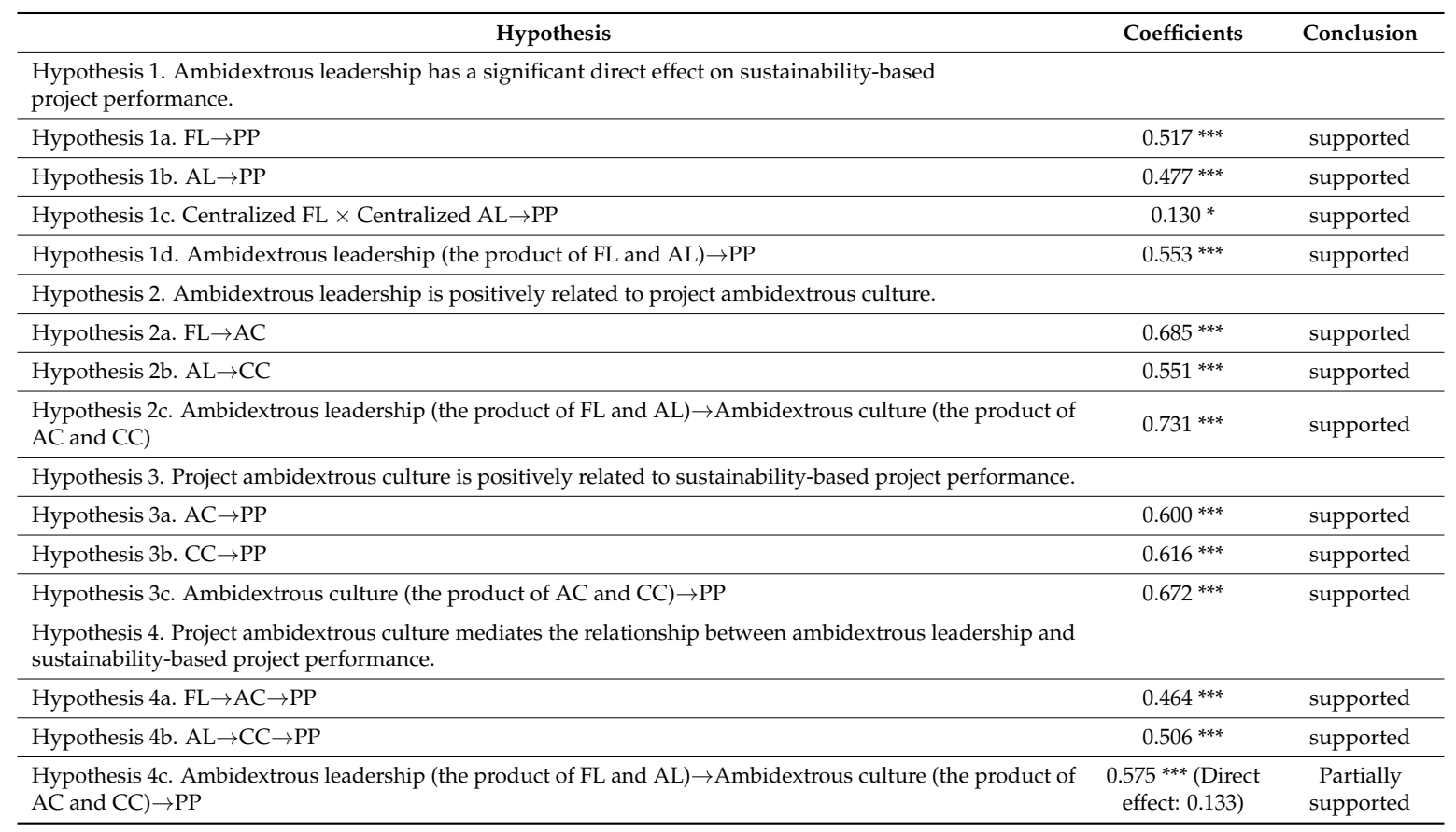

Notes: FL, transformational leadership; AL, transactional leadership; AC, adaptive culture; CC, consistent culture; $\mathrm{PP}$, sustainability-based project performance. ${ }^{* * *} p<0.001,{ }^{*} p<0.05$. 


\section{Discussions}

\subsection{The Direct Effects of Ambidextrous Leadership on Project Performance}

Previous studies indicated that leadership has been be considered as an important precursor of organizational performance, especially at the individual level but also at the organizational level [26,91]. The goal of this study was to extend the research towards construction projects and to provide an empirical test for the ambidexterity theory of leadership and culture in project management field. This study found the preliminary support for the role of ambidextrous leadership and organizational ambidexterity in construction projects. Using a sample of managers and engineers from different job positions in construction project-based organizations, this study indicated that transformational leadership positively predicted sustainability-based project performance, whereas transactional leadership also showed the significant effect. Importantly, the project performance was highest when both transformational leadership and transactional leadership were high, whereas project performance was lower when only transactional leadership style was high or when both leadership behaviors were low.

However, the current findings have not provide sufficient evidence that there were significant difference for the cases when only transformational leadership behavior was high or both leadership behaviors were high. According to the ambidexterity theory of leadership for innovation proposed by Rosing et al. [25], the interaction of two complementary leadership behaviors-opening and closing behaviors would be more successful and effective. Opening behaviors involve giving room for independent thinking and encouraging to do things differently, while closing behaviors include setting guidelines and supervising target achievement [26]. Transformational leadership behaviors involve that leaders encourage independent and creative thinking, providing a mutual vision and nurturing the intrinsic needs [15]. Thus, the transformational leaders may possess similar features as the opening and closing behaviors, and the ambidextrous leadership behaviors were summarized under the umbrella of transformational leadership. In this study we argued that ambidextrous leadership was related to, but different from transformational leadership and transactional leadership, even the broader meaning of transformational leadership behavior. Although there were no significant differences between both high behaviors group and only transformational leadership high group, the regression equation results and structural equation modeling results also suggested that the combined leadership behaviors predict project performance beyond the single effect of transformational leadership. In general, transformational leadership or transactional leadership has been considered as the successful leadership behavior or style in the organization management process. Our findings suggest that researches focusing on the effect of single and stable antecedents were insufficient.

\subsection{The Mediating Effects of Ambidextrous Culture}

Our study provides evidence that the ambidextrous culture is possible in a project-based organization. In other words, the adaptive culture and consistent culture, if fostered properly, could be complementary and compatible in the project management and implementation process. The adaptive culture could promote diverse knowledge, and various viewpoints to encourage the development under rules or disciplines [21], which was associated with transformational behaviors. The consistent culture would ensure the behavior norms in terms of the shared vision and direction to achieve the project goal, which also was associated with transactional behaviors. Besides, the ANOVA findings also stated that the adaptive and consistent culture could mutually reinforce each other, thus enabling project performance.

Moreover, the full mediating effect of ambidextrous culture on the relationship between ambidextrous leadership and project performance, suggested that an ambidextrous culture was a widely dispersed organizational resource [19], on which ambidextrous leadership is developed and indirectly facilitated the project outcomes. In line with earlier research (e.g., Han et al. [41]), 
the ambidextrous culture predicted the performance but in the innovation process, and played a partial mediating role. Considering the Chinese context, although the transformational and transactional leadership have provided a stable base and strong influence for effective organizational performance, the interaction and exchange at the project level would be an important path between ambidextrous leadership and project performance. The formation of the ambidextrous culture was the part of the exchange at the project level, indicating that the project leaders improved the performance by shaping the adaptive culture and consistent culture to make the project-based organization and members more flexible and integrative, as well as to allow change and ensure the goal achievement.

\section{Conclusions and Implications}

\subsection{Conclusions}

Extending research on leadership and performance, the present study highlights the ambidextrous characteristic of leadership and culture to promote the sustainability project performance in the setting of construction projects. Specifically, drawing from ambidextrous theory and leadership theory, this study examines the inner mechanism whereby ambidextrous leadership contributes to sustainability-based project performance via ambidextrous culture. In this study, transformational leadership and transactional leadership formed what we call ambidextrous leadership. Moreover, the adaptive culture and the consistent culture were considered as ambidextrous culture. This research examines the mechanism that how ambidextrous leadership contributes to sustainability-based project performance. These findings reveal the mediation process underlying ambidextrous culture. That is, leaders could promote performance at the project level by fostering the adaptive or flexible culture and the consistent or normative culture, and the condition under the high transformational leadership behaviors and high transactional leadership behaviors would be better for project performance. Despite some potential methodological limits, this theory-based and empirical study could be beneficial for obtaining a better understanding of the combination of leadership behaviors and cultures that facilitate project performance for sustainable development. Our hope is that this study will extend the interest for exploring the influence of leaders' behaviors or styles on project outcomes including but not limited to the firm level.

\subsection{Theoretical Contributions}

This paper provides new directions for studying organizational ambidexterity and addressing effective leadership and culture practice in construction projects. Although organizational ambidexterity has been studied since 1970s (e.g., Duncan [8]), the theory of ambidexterity has been extended to the fields of leadership (e.g., Rosing [25]), culture (e.g., Wang and Rafiq [19]), and the firm level (e.g., Lubatkin et al. [11]). Here, we contribute theoretically by showing that ambidexterity is also associated with leadership and culture at the project level. Our framework addresses the increasing complexities and changing trends in the construction project context. Single leadership models may be effective for simple and stable contexts, nonetheless, dynamic environments and complex project characteristic call for new leadership paradigms [92]. By responding to the dynamic environment and project complexity, the simple and static management approaches cannot meet the demands, which orient project leaders to effectively position themselves in the ever-changing project-based organization. In short, the ambidexterity framework of project-based organization broadens our perspective regarding leadership models in complex construction projects.

\subsection{Practical Implications}

The results of this study provide several practical implications. Our findings highlight that ambidextrous leadership and ambidextrous culture could be developed at the project level and not only at the firm level. The ambidextrous leadership exerts a positive effect on project performance at least above and beyond the effect of only transactional leadership or non-specific leadership 
behaviors, and the ambidextrous culture also has a positive effect on project performance above and beyond the effect of one culture. These results suggest that a project-based organization should develop leadership styles or programs aimed at establishing the leaders' confidence in fostering culture and boosting performance. Previous studies have recommend transformational leadership or transactional leadership as supportive for organization climate in construction firms (e.g., Chan et al. [55]) or innovation outcomes in construction projects (e.g., Park et al. [93]). However, given the demonstrated positive indirect effect of ambidextrous culture between ambidextrous leadership and project performance, it may be more efficient for project-based organizations to concentrate on fostering and developing adaptive and consistent culture, which will be beneficial for both project leaders and project performance.

Additionally, according to the results of the variance analysis, there was no difference under the condition of only transformational leadership or both high leadership styles. Such findings suggest that the transformational leadership possesses the opening leader behavior to support the organizational change and flexibility, and the closing leader behaviors to follow the existing rules. In short, the uncovered differentiation influence of single leadership and ambidextrous leadership lead us to advocate that project-based organizations launch intervention programs (e.g., training the project leader). Similarly, the different effects of single culture and ambidextrous culture on project performance also lead us to identify the role of culture in the construction projects. These intervention programs or measures should be designed and executed in such a way that would increase the interaction or connections between managers and members, and promote the mutual communication or cooperation.

\subsection{Limitations and Directions for Future Research}

This study indicates the empirical test of the ambidexterity theory of leadership and culture for project performance, and it is not surprising that there are a number of limitations that should be addressed in future research. First, the cross-sectional character of the research design cannot obtain the conclusions regarding causality or variation of variables over time. In addition, the project culture or climate may be considered as control variables [94]. Although the post hoc analysis using variance analysis was employed in this study, future research could collect longitudinal data to predict dynamic changes in leadership behaviors and project performance over time. Second, the sample size was 217 participants who engaged in construction projects. The results of the relationships among central variables were consistent with the ambidextrous leadership theory. Nevertheless, future research could collect larger and more representative samples to extend the current findings. Besides, a widely used and well-validated scale or measure was important to reduce the bias or error and ensure the reliability and validity.

A possible direction for future research is to find more effective mediating mechanisms or examine the boundary condition. An interesting avenue for future research could be to examine whether the low level of individual behavior mediates the interaction of leaders' behaviors on organizational performance, and when or where the ambidextrous leadership would act on project performance. Finally, future research could also expand the findings of this study by focusing on the multi-level effects, crossing individual, project level and firm level.

Acknowledgments: This study is supported by the National Natural Science Foundation of China (71701083, 71561009 and 71761021), China Postdoctoral Science Foundation (2016M590605 and 2017T100477), Postdoctoral Science Foundation of Jiangxi Province (2016KY27), Social Science Planning Foundation of Jiangxi Province (16GL32), and Natural Science Foundation of Jiangxi Province (S2017QNJJB0493), and Talent Training Foundation of Yunnan Province (KKSY201606041).

Author Contributions: Junwei Zheng designed this study and completed the paper in English, Guangdong Wu participated in drafting the paper and critically revised it for important intellectual content, Hongtao Xie provided many good research advices and revised the manuscript, Hui Xu made a comprehensive English revision.

Conflicts of Interest: The authors declare no conflict of interest. 


\section{References}

1. Bankvall, L.; Bygballe, L.E.; Dubois, A.; Jahre, M. Interdependence in construction projects and its supply chains. Supply Chain Manag. 2010, 15, 385-393. [CrossRef]

2. Havenvid, M.I. Competition versus interaction as a way to promote innovation in the construction industry. IMP J. 2015, 9, 46-63. [CrossRef]

3. Seaden, G.; Manseau, A. Public policy and construction innovation. Build. Res. Inf. 2001, 29, $182-196$. [CrossRef]

4. Davis, P.; Gajendran, T.; Vaughan, J.; Owi, T. Assessing construction innovation: Theoretical and practical perspectives. Constr. Manag. Econ. 2016, 16, 104-115. [CrossRef]

5. Miron, E.; Erez, M.; Naveh, E. Do personal characteristics and cultural values that promote innovation, quality, and efficiency compete or complement each other? J. Organ. Behav. 2004, 25, 175-199. [CrossRef]

6. Ghoshal, S.; Bartlett, C.A. The Individualized Corporation; Harper Collins: New York, NY, USA, 1997.

7. Nemanich, L.A.; Vera, D. Transformational leadership and ambidexterity in the context of an acquistion. Leadersh. Q. 2009, 20, 19-33. [CrossRef]

8. Duncan, R. The ambidextrous organization: Designing dual structures for innovation. In The Management of Organization; Killman, R.H., Pondy, L.R., Sleven, D., Eds.; North Holland: New York, NY, USA, 1976; pp. 167-188.

9. Tushman, M.L.; O’Reilly, C.A. Ambidextrous organizations: Managing evolutionary and revolutionary change. Calif. Manag. Rev. 1996, 38, 8-30. [CrossRef]

10. Gibson, C.B.; Birkinshaw, J. The antecedents, consequences, and mediating role of organizational ambidexterity. Acad. Manag. J. 2004, 47, 209-226. [CrossRef]

11. Lubatkin, M.H.; Simsek, Z.; Ling, Y.; Veiga, J.F. Ambidexterity and performance in small- to medium-sized firms: The pivotal role of top management team behavioral integration. J. Manag. 2006, 32, 646-672. [CrossRef]

12. Smith, W.K.; Tushman, M.L. Managing strategic contradictions: A top management model for managing innovation streams. Organ. Sci. 2005, 16, 522-536. [CrossRef]

13. Ancona, D.G.; Goodman, P.S.; Lawrence, B.S.; Tushman, M.L. Time: A new research lens. Acad. Manag. Rev. 2001, 26, 645-663.

14. Bass, B.M.; Avolio, B.J.; Jung, D.I.; Berson, Y. Predicting unit performance by assessing transformational and transactional leadership. J. Appl. Psychol. 2003, 88, 207-218. [CrossRef] [PubMed]

15. Bass, B.M. Leadership and Performance beyond Expections; Free Press: New York, NY, USA, 1985.

16. Podsakoff, P.M.; MacKenzie, S.B.; Moorman, R.H.; Fetter, R. Transformational leader behaviors and their effects on followers' trust in leader, satisfaction, and organizational citizenship behaviors. Leadersh. Q. 1990, 1, 107-142. [CrossRef]

17. Sosik, J.J.; Avolio, B.J.; Kahai, S.S. Effects of leadership style and anonymity on group potency and effectiveness in a group decision support system environment. J. Appl. Psychol. 1997, 82, 89-103. [CrossRef]

18. Kahai, S.S.; Sosik, J.J.; Avolio, B.J. Effects of leaderhsip style, anonymity, and rewards on creativity-relevant processes and outcomes in an electronic meeting system context. Leadersh. Q. 2003, 14, 499-524. [CrossRef]

19. Wang, C.L.; Rafiq, M. Ambidextrous organizational culture, contextual ambidexterity and new product innovation: A comparative study of UK and Chinese high-tech firms. Br. J. Manag. 2014, 25, 58-76. [CrossRef]

20. Denison, D.R.; Mishra, A.K. Toward a theory of organizational culture and effectiveness. Organ. Sci. 1995, 6, 204-223. [CrossRef]

21. Güttel, W.H.; Konlechner, S.W. Continously hanging by a thread: Managing contextually ambidextrous organizations. Schmalenbach Bus. Rev. 2009, 61, 149-171. [CrossRef]

22. Raisch, S.; Birkinshaw, J. Organizational ambidexterity: Antecedents, outcomes, and moderators. J. Manag. 2008, 34, 375-409. [CrossRef]

23. He, Z.L.; Wong, P.K. Exploration vs. exploitation: An empirical test of the ambidexterity hypothesis. Organ. Sci. 2004, 15, 481-494. [CrossRef]

24. Siggelkow, N.; Levinthal, D.A. Temporarily divide to conquer: Centralized, decentralized, and reintegrated organizational approaches to exploration and adaptation. Organ. Sci. 2003, 14, 650-669. [CrossRef]

25. Rosing, K.; Frese, M.; Bausch, A. Explaining the heterogeneity of the leadership-innovation relationship: Ambidextrous leadership. Leadersh. Q. 2011, 22, 956-974. [CrossRef] 
26. Zacher, H.; Rosing, K. Ambidextrous leadership and team innovation. Leadersh. Organ. Dev. J. 2015, 36, 54-68. [CrossRef]

27. Martin, S.L.; Campbell, E.M. Directive versus empowering leadership: A field experiment comparing impacts on task proficiency and proactivity. Acad. Manag. J. 2013, 56, 1372-1395. [CrossRef]

28. Mitchell, T.R.; James, L.R. Building better theory: Time and specification of when things happen. Acad. Manag. Rev. 2001, 26, 530-547.

29. Baškarada, S.; Watson, J.; Cormarty, J. Balancing transactional and transformational leadership. Int. J. Organ. Anal. 2017, 25, 506-515. [CrossRef]

30. Rao-Nicholson, R.; Khan, Z.; Akhtar, P.; Merchant, H. The impact of leadership on organizational ambidexterity and employee psychological safety in the global acquisitions of emerging market multinationals. Int. J. Hum. Resour. Manag. 2016, 27, 2461-2487. [CrossRef]

31. Schulte, B.; Koller, H.; Andresen, F.; Kreutzmann, A. How to manage the unmanageable? Leadership in coping with communities of practice. In Proceedings of the European Conference on Knowledge Management, Coleraine, UK, 1-2 September 2016.

32. Tuan, L.T. Reform in public organizations: The roles of ambidextrous leadership and moderating mechanisms. Public Manag. Rev. 2017, 19, 518-541. [CrossRef]

33. Vargas, M.I.R. Determinant factors for small business to achieve innovation, high performance and competitiveness: Organizational learning and leadership style. Procedia Soc. Behav. Sci. 2015, 169, 43-52. [CrossRef]

34. Baškarada, S.; Watson, J.; Cormarty, J. Leadership and organizational ambidexterity. J. Manag. 2016, 35, 778-788. [CrossRef]

35. Cunha, M.P.; Fortes, A.; Gomes, E.; Rego, A.; Rodrigues, F. Ambidextrous leadersip, paradox and contingency: Evidence from Angola. Int. J. Hum. Resour. Manag. 2016, 1-26. [CrossRef]

36. Denison, D. Corporate Culture and Organizational Effectiveness; Wiley: New York, NY, USA, 1990.

37. Denison, D.R. What is the difference between organizaitonal culture and organizational climate? A native's point of view on a decade of paradigm wars. Acad. Manag. Rev. 1996, 21, 619-654.

38. Schein, E.H. Organizational culture. Am. Psychol. 1990, 45, 109-119. [CrossRef]

39. Rink, F.; Ellemers, N. Diversity as a basis for shared organizational identity: The norm congruity principle. J. Manag. 2007, 18, S17-S27. [CrossRef]

40. Xu, Y.; Gu, Q. Ambidextrous culture and organizational creativity: Base on the contingency perspective of organizational structure. In Proceedings of the 3rd China Human Resource Management Conference; Management Society of China: Nanjing, China, 2014; pp. 229-243.

41. Han, Y.; Luo, J.; Zhong, J. The research on the effects of ambidextrous leadership on team innovation performance: From the perspective of routine practice. J. Manag. Sci. 2016, 29, 70-85.

42. Junni, P.; Sarala, R.M.; Taras, V.A.S.; Tarba, S.Y. Organizational ambidexterity and performance: A meta-analysis. Acad. Manag. Perspect. 2013, 27, 299-312. [CrossRef]

43. Lee, J.Y.; Seo, Y.; Jeung, W.; Kim, J.-H. How ambidextrous organizational culture affects job performance: A multilevel study of the mediating effect of psychological capital. J. Manag. Organ. 2017, 1-16. [CrossRef]

44. Giritli, H.; Oraz, G.T. Leadership styles: Some evidence from the Turkish construction industry. Constr. Manag. Econ. 2004, 22, 253-262. [CrossRef]

45. Cleland, D.I. Project Management: Strategic Design and Implementation, 2nd ed.; McGraw Hill: New York, NY, USA, 1995.

46. Naum, S. People E Organizational Management in Construction; Thoms Telford: London, UK, 2001.

47. Harvey, R.C.; Ashworth, A. The Construction Industry of Great Britain; Butterworth-Heinemann: Oxford, UK, 1993.

48. Zhao, X.; Hwang, B.-G.; Lee, H.N. Identifying critical leadership styles of project managemers for green building projects. Int. J. Constr. Manag. 2016, 16, 150-160.

49. Rowlinson, S.; Ho, T.K.K.; Po-Hung, Y. Leadership styles of construction managers in Hong Kong. Constr. Manag. Econ. 1993, 11, 455-465. [CrossRef]

50. Schreuders, J.; Legesse, A. Organizational ambidexterity: How small technology firms balance innovation and support. Technol. Innov. Manag. Rev. 2012, 2, 17-21. 
51. Chang, Y.-Y. High-performance work systems, joint impact of transformational leadership, and empowerment climate and organizational ambidexterity: Cross level evidence. J. Organ. Chang. Manag. 2016, 29, 424-444. [CrossRef]

52. Staniewski, M.W.; Nowacki, R.; Awruk, K. Entrepreneurship and innovativeness of small and medium-sized construction enterprises. Int. Entrep. Manag. J. 2016, 12, 861-877. [CrossRef]

53. Avolio, B.J.; Bass, B.M.; Jung, D. Reexamining the components of transformational and transactional leadership using the Multifactor Leadership Questionnaire. J. Occup. Organ. Psychol. 1999, 7, 441-462. [CrossRef]

54. Bycio, P.; Hackett, R.D.; Allen, J.S. Further assessments of Bass's (1985) conceptualization of transactional and transformational leadership. J. Appl. Psychol. 1995, 80, 468-478. [CrossRef]

55. Chan, I.Y.S.; Liu, A.M.M.; Fellows, R. Role of leadership in fostering an innovation climate in constrction firms. J. Manag. Eng. 2014, 30, 6014003. [CrossRef]

56. Podsakoff, P.M.; MacKenzie, S.B.; Bommer, W.H. Transformational leadership behaviors and sbustitutes for leadership as determinants of employee satisfaction, commitment, trust, and organizational citizenship behaviors. J. Manag. 1996, 22, 159-298.

57. Bass, B.M. Two decades of research and development in transformational leadership. Eur. J. Work Organ. Psychol. 1999, 8, 9-32. [CrossRef]

58. Mao, M.; Long, L. Influence of transformational leadership on organizational changes: An empirical study of Chinese construction enterprises. In Proceedings of the 2007 International Conference on Management Science \& Engineering, Harbin, China, 20-22 August 2007; pp. 1505-1510.

59. Brandt, T.; Laitinen, E.K.; Laitinen, T. The effect of transformational leadership on the profitability of Finnish firms. Int. J. Organ. Anal. 2016, 24, 81-106. [CrossRef]

60. Politis, J.D. Transformational and transactional leadership enabling (disabling) knowledge acquisition of self-managed teams: The consequences for performance. Leadersh. Organ. Dev. J. 2002, 23, 186-197. [CrossRef]

61. Zheng, J.; Wu, G.; Xie, H. Impacts of leadership on project-based organizational innovation performance: The mediator of knowledge sharing and moderator of social capital. Sustainability 2017, 9, 1893. [CrossRef]

62. Liu, A.M.M.; Fang, Z. A power-based leadership approach to project management. Constr. Manag. Econ. 2006, 24, 497-507. [CrossRef]

63. Gebert, D.; Boerner, S.; Kearney, E. Fostering team innovation: Why is it important to combine opposing action strategies? Organ. Sci. 2010, 21, 593-608. [CrossRef]

64. Mccarthy, I.P.; Gordon, B.R. Achieving contextual ambidexterity in R\&D organizations: A management control system approach. Res. Dev. Manag. 2011, 41, 240-258.

65. Bandura, A. Social congnitive theory: An agentic perspective. Annu. Rev. Psychol. 2001, 52, 1-26. [CrossRef] [PubMed]

66. Grattion, L.; Erickson, T.J. Eight ways to build collaborative teams. Harv. Bus. Rev. 2007, 85, 100-109.

67. Probst, G.; Raisch, S.; Tushman, M.L. Amidextrous leadership: Emerging chanllenges for business and HR leaders. Organ. Dyn. 2011, 40, 326-334. [CrossRef]

68. Jung, D.; Bass, B.M.; Sosik, J.J. Bridging leadership and culture: A theoretical consideration of transformational leadersihp and collectivistic cultures. J. Leadersh. Stud. 1995, 2, 3-18. [CrossRef]

69. Jackson, T.A.; Meyer, J.P.; Wang, X.-H. Leadership, commitment, and culture: A meta-analysis. J. Leadersh. Organ. Stud. 2013, 20, 84-106. [CrossRef]

70. Cohen, W.; Levinthal, D. Absorptive capacity: A new perspective on learning and innovation. Adm. Sci. Q. 1990, 35, 128-152. [CrossRef]

71. Ferner, A.; Almond, P.; Colling, T. Institutional theory and the cross-national transfer of employment policy: The case of 'workforce diversity' in US multinationals. J. Int. Bus. Stud. 2005, 36, 304-321. [CrossRef]

72. Thongpapanl, N.; Clercq, D.D.; Dimov, D. An investigation of the performance consequences of alignment and adaptability: Contingency effects of decision autonomy and shared responsibility. Res. Dev. Manag. 2012, 42, 14-30. [CrossRef]

73. Gittell, J.H. Coordinating mechanisms in care provider groups: Relational coordination as a mediator and input uncertainty as a moderator of performance effects. Manag. Sci. 2002, 48, 1408-1426. [CrossRef]

74. Cooper, D.R.; Schindler, P.S. Business Research Methods; McGraw Hill: Boston, MA, USA, 2006. 
75. Cao, Q.; Gedajlovic, E.; Zhang, H. Unpacking organizational ambidexterity: Dimensions, contingencies, and synergistic effects. Organ. Sci. 2009, 20, 781-796. [CrossRef]

76. Li, C.; Shi, K. The structure and measurement of transformational leadership in China. Acta Psychol. Sin. 2005, 37, 803-811. [CrossRef]

77. Chen, X.; Wang, S.; Yang, L. The impact mechanism of transformational leadership on firm performance: Based on a survey of SMEs' leaders. Sci. Sci. Manag. S. T. 2012, 33, 160-171.

78. Waldman, D.A.; Ramirez, G.G.; House, R.J.; Puranam, P. Does leadership matter? CEO leadership attributes and profitability under conditions of perceived environmental uncertainty. Acad. Manag. J. 2001, 44, 134-143. [CrossRef]

79. Yang, H.; Yang, J. Transactional leadership, competitive intensity, technological innovation choices and firm performance. J. Manag. Sci. 2015, 28, 1-10.

80. Ozorhon, B.; Oral, K.; Demirkesen, S. Investigating the components of innovation in construction projects. J. Manag. Eng. 2016, 32, 4015052. [CrossRef]

81. Hair, J.F.J.; Anderson, R.E.; Black, W.C. Multivariate Data Analysis, 5th ed.; Prentice Hall: Upper Saddle River, NJ, USA, 1998.

82. Fornell, C.; Larcker, D.F. Evaluating structural equation models with unobservable variables and measurement error. J. Mark. Res. 1981, 18, 39-50. [CrossRef]

83. Baron, R.M.; Kenny, D.A. The moderator mediator variable distinction in social psychological research conceptual strategic and statistical considerations. J. Personal. Soc. Psychol. 1986, 51, 1173-1182. [CrossRef]

84. Hayes, A.F. Beyond Baron and Kenny: Statistical mediation analysis in the new millennium. Commun. Monogr. 2009, 76, 408-420. [CrossRef]

85. Podsakoff, P.M.; Organ, D.W. Self-reports in organizaitonal research: Problems and prospects. J. Manag. 1986, 12, 531-544.

86. Malhotra, N.K.; Kim, S.S.; Patil, A. Common method variance in is research: A comparision of alternative approaches and a reanalysis of past research. Manag. Sci. 2006, 52, 1865-1883. [CrossRef]

87. Bentler, P.M.; Bonett, D.G. Significance tests and goodness of fit in the analysis of covariance structures. Psychol. Bull. 1980, 88, 588-606. [CrossRef]

88. Hu, L.; Bentler, P.M. Cuttoff criteria for fit indexes in covariance structure analysis: Conventional criteria versus new alternatives. Struct. Equ. Model. 1999, 6, 1-55. [CrossRef]

89. Browne, M.W.; Cudeck, R. Alternative ways of assessing model fit. In Testing Structural Equation Models; Bollen, K.A., Long, J.S., Eds.; Sage Publications: Newbury Park, CA, USA, 1993; pp. 136-162.

90. Becker, T.E. Potential problems in statistical control of variables in organizational research: A qualitative analysis with recommendations. Organ. Res. Methods 2005, 8, 274-289. [CrossRef]

91. Ozorhon, B.; Abbott, C.; Aouad, G. Integration and leadership as enablers of innovation in construction: Case study. J. Manag. Eng. 2014, 30, 256-263. [CrossRef]

92. Uhl-Bien, M.; Marion, R.; McKelvey, B. Complexity leadership theory: Shifting leadership from the industrial age to the knowledge ERA. Leadersh. Q. 2007, 18, 298-318. [CrossRef]

93. Park, M.; Nepal, M.P.; Dulaimi, M.F. Dynamic modeling for construction innovation. J. Manag. Eng. 2004, 20, 170-177. [CrossRef]

94. Eisenbeiss, S.A.; van Knippenberg, D.; Boerner, S. Tranformational leadership and team innovation: Integrating team climate principles. J. Appl. Psychol. 2008, 93, 1438-1446. [CrossRef] [PubMed]

(C) 2017 by the authors. Licensee MDPI, Basel, Switzerland. This article is an open access article distributed under the terms and conditions of the Creative Commons Attribution (CC BY) license (http://creativecommons.org/licenses/by/4.0/). 